\title{
ANALISIS PENILAIAN HARGA WAJAR SAHAM MENGGUNAKAN PENDEKATAN DIVIDEND DISCOUNT MODEL, PRICE EARNING RATIO DAN PRICE TO BOOK VALUE
}

\section{(Studi pada Perusahaan Pertambangan Batubara yang Terdaftar di Indeks LQ45 Periode 2010-2014)}

\author{
Oleh: \\ Nurbani Aulia Ismunarti ${ }^{1)}$ \\ Drs. Bambang Sunarko, M.M ${ }^{2)}$ \\ Drs. Tohir, M.M ${ }^{3)}$ \\ ${ }^{1)}$ Mahasiswa Fakultas Ekonomi dan Bisnis Universitas Jenderal Soedirman \\ 2) 3) Dosen Fakultas Ekonomi dan Bisnis Universitas Jenderal Soedirman
}

\begin{abstract}
The purpose of this research is to determine the intrinsic value of coal mining company stock listed in LQ45 Index during 2010-2014 period used Dividend Discount Model (DDM) Pertumbuhan Berganda, Price Earning Ratio (PER) and Price to Book Value $(P B V)$ approach. Intrinsic value will compared with market stock value, henceforth be one of basic for taking investment decision in capial market. Difference of intrinsic stock value with market stock value is tasted by Paired Sample T-Test. For this research, the sample used is PT. Adaro Energy Tbk (ADRO), PT. Indo Tambangraya Megah Tbk (ITMG) and PT. Bukit Asam Tbk (PTBA).

The result of this research showed that the market stock value of the coal mining company listed in LQ45 Index is higher than intrinsic stock value (overvalued) based DDM Pertumbuhan Berganda and PBV approach. While based PER approach, the market stock value of the coal mining company is lower than intrinsic stock value (undervalued). And then, for the result of paired sample t-test showed that based on DDM Pertumbuhan Berganda, PER and PBV approach has a significant difference between intrinsic value with market stock value.
\end{abstract}

Key words : Market Stock Value, Intrinsic Value, Dividend Discount Model (DDM) Pertumbuhan Berganda, Price Earning Ratio (PER), Price to Book Value (PBV), LQ45 Index. 


\title{
Performance - Vol.23 No.2 September 2016
}

\begin{abstract}
ABSTRAK
Tujuan dari penelitian ini adalah untuk menentukan nilai intrinsik dari perusahaan tambang batu bara terdaftar pada indeks LQ45 sepanjang periode 2010 2014 menggunakan pendekatan Model Dividend Terdiskonto (DDM) Pertumbuhan Berganda, Rasio Harga Pendapatan (PER), dan Harga Nilai Buku (PBV). Nilai intrinsik akan dibandingkan dengan nilai pasar saham, yang kemudian dapat digunakan sebagai dasar penentuan keputusan investasi di pasar modal. Perbedaan dari nilai intrinsik saham dengan nilai pasar saham dapat dihitung melalui Paired-Sample T-Test. Sampel yang digunakan pada penelitian ini terdiri PT. Adaro Energy Tbk (ADRO), PT. Indo Tambangraya Megah Tbk (ITMG) dan PT. Bukit Asam Tbk (PTBA).

Hasil penelitian menunjukkan bahwa nilai pasar saham dari perusahaan tambang batu bara yang terdaftar pada indeks LQ45 lebih tinggi dari nilai intrinsik saham (overvalued) berdasarkan pendekatan DDM Pertumbuhan Berganda dan PBV. Sedangkan berdasarkan pendekatan PER, nilai pasar saham perusahaan tambang batu bara lebih rendah dari nilai intrinsik saham (undervalued). Kemudian hasil Paired Sample t-test menunjukkan bahwa berdasarkan pendekatan DDM Pertumbuhan Berganda, PER, dan PBV memiliki perbedaan yang signifikan antara nilai intrinsik dan nilai pasar saham.
\end{abstract}

Kata Kunci : Nilai Pasar Saham, Nilai Intrinsik Saham, Model Dividend Terdiskonto (DDM) Pertumbuhan Berganda, Rasio Harga Pendapatan (PER) Harga Nilai Buku (PBV), Indeks LQ45.

\section{PENDAHULUAN}

Indonesia merupakan negara kepulauan terbesar di dunia dan memiliki letak geografis yang sangat strategis sehingga membuat Indonesia menjadi negara dengan jumlah kekayaan sumber daya alam terbesar di dunia. Sumber daya alam Indonesia ini tidak hanya berasal dari pertanian, kelautan dan perikanan, kehutanan serta perkebunan, tetapi juga dari pertambangan dan energi.

Sektor pertambangan dan energi merupakan salah satu sumber daya alam dengan tingkat ekspor dan sumber penerimaan devisa tertinggi di Indonesia. Namun, kebutuhan yang semakin besar 


\section{Performance - Vol.23 No.2 September 2016}

serta ketergantungan akan penggunaan bahan bakar minyak dan gas menyebabkan kedua sumber daya alam ini mengalami eksploitasi yang cukup mengkhawatirkan. Untuk itu, pemerintah Indonesia berupaya menggali sumber energi alternatif lain guna mengurangi ketergantungan minyak dan gas. Salah satu energi alternatif yang memiliki jumlah cukup besar di Indonesia adalah batubara.

Batubara atau bahan bakar fosil merupakan sumber energi alternatif terpenting yang digunakan untuk pembangkit listrik dan juga berfungsi sebagai bahan bakar pokok produksi baja dan semen. Menurut BP Statistical Review of World Energy 2016, Indonesia merupakan salah satu produsen dan eksportir batubara terbesar di dunia dan berada di urutan keempat setelah Tiongkok, Amerika Serikat, dan Australia pada tahun 2014. Untuk cadangan batubara global, Indonesia berada di peringkat sepuluh dengan memiliki sekitar 3,1 persen dari total cadangan batubara global. Ekspor batubara Indonesia berksar antara 70 sampai dengan 80 persen dari total produksi batubara, serta sisanya dijual di pasar domestik.
Krisis keuangan global tahun 2008 membuat harga-harga komoditas menurun drastis dan nyatanya memberikan dampak yang sangat besar bagi industri pertambangan batubara di Indonesia yakni menurunnya antusiasme para penambang batubara untuk memproduksi dan menjual batubara karena semakin rendahnya harga batubara global. Walaupun demikian, perkembangan sumber energi alternatif tidak menunjukkan indikasi bahwa ketergantungan pada batubara akan menurun secara signifikan dalam waktu dekat, sehingga batubara akan terus menjadi sumber energi vital.

Batubara juga merupakan satusatunya sumber daya alam mentah yang dapat terus diekspor tanpa harus diolah terlebih dahulu guna menambahkan nilai pada produk. Selain itu, batubara merupakan industri pertambangan dengan tingkat kerentanan yang lebih rendah terhadap harga pasar dunia dibandingkan dengan sumber energi lain seperti gas alam dan sebagainya. Sehingga hal ini menjadi salah satu faktor yang mendorong investasi pada industri pertambangan batubara masih diminati banyak investor baik dalam maupun luar negeri. 
Investasi pada aset finansial likuidasi perdagangan dan kapitalisasi berupa saham merupakan salah satu jenis pasar.

investasi yang paling diminati, hal ini tentu dikarenakan tingkat pengembalian investasi (return) pada sekuritas ini adalah yang paling tinggi dibandingkan dengan jenis sekuritas lainnya.

Saham dikenal dengan karakteristik high risk-high return yang berarti saham merupakan surat berharga dengan risiko tinggi tetapi juga memberikan peluang keuntungan yang tinggi pula. Saham memungkinkan investor mendapatkan dividen (return) dan keuntungan (capital gain) dalam jumlah yang besar dalam waktu yang singkat. Namun, saham juga merupakan sekuritas yang sangat rentan mengalami fluktuasi harga yang dapat membuat investor mengalami kerugian dalam waktu singkat.

Pergerakan harga suatu saham dapat dilihat melalui indeks harga saham. Terdapat beberapa indeks harga saham yang sering digunakan di Indonesia, yakni Indeks Harga Saham Gabungan (IHSG) yang merupakan indeks yang berasal dari semua saham tercatat sebagai komponen perhitungan indeks serta Indeks LQ45 yang merupakan indeks yang terdiri atas 45 saham pilihan mengacu pada variabel
Selain itu, fluktuasi harga saham dipengaruhi oleh faktor internal (kinerja perusahaan) dan faktor eksternal (kondisi ekonomi makro). Dan oleh karenanya, investor harus lebih teliti dan berhati-hati dalam pembuatan keputusan investasi dengan memahami berbagai informasi yang berhubungan dengan perusahaan penerbit saham sehingga melalui informasi tersebut dapat dijadikan dasar untuk melakukan analisis saham yang berguna untuk menilai saham apa saja yang akan dipilih dan bagaimana tingkat return yang diharapkan saham tersebut.

Analisis saham dapat dilakukan dengan menggunakan analisis fundamental. Dalam analisis fundamental terdapat beberapa pendekatan yang dapat digunakan untuk menghitung nilai intrinsik suatu saham. Pendekatanpendekatan tersebut yaitu : (1) Dividend Discount Model (DDM) yang merupakan model untuk menentukan estimasi harga saham dengan mendiskontokan semua aliran dividen yang akan diterima di masa datang (Tandelilin, 2001:186).

Dalam penelitian Triyati Fabrina Simamora (2009) mengungkapkan bahwa 


\section{Performance - Vol.23 No.2 September 2016}

terjadi perbedaan antara harga intrinsik saham dengan harga pasar saham melalui pendekatan DDM, sedangkan pada pendekatan PBV tidak terjadi perbedaan antara nilai intrinsik dengan harga pasar saham. Hal ini juga didukung oleh penelitian oleh Ernia Fayana dan Singgih Jatmiko (2012) serta Adrian Manurung (2007) yang menyatakan bahwa terdapat perbedaan yang signifikan antara nilai intrinsik dengan harga pasar suatu saham melalui pendekatan Dividend Discount Model.

(2) Price Earning Ratio (PER) merupakan metode penilaian saham yang menggambarkan rasio atau perbandingan antara harga saham terhadap laba (earnings) perusahaan dan rasio ini menunjukkan berapa besar investor menilai harga dari saham terhadap kelipatan dari laba (Jogiyanto, 2003:205). Penelitian Rizki Nanda Khairi (2014) menunjukkan bahwa saham memiliki perbedaan dengan harga pasar saham baik menggunakan pendekatan PER maupun PBV. Selain itu, penelitian Elvianna Khairi (2011) menjelaskan hal serupa bahwa nilai intrinsik berdasarkan pendekatan PER memiliki perbedaan dengan harga pasar, namun pada penelitian Andrian Manurung (2007) menyatakan hal sebaliknya.

(3) Price to Book Value (PBV) merupakan pendekatan untuk menilai suatu saham dengan menghubungkan antara harga pasar saham dengan nilai buku per lembar saham (Tandelilin, 2003:194). Ernia Fayana dan Singgih Jatmiko (2012) melakukan penelitian nilai intrinsik saham dengan menggunakan pendekatan PBV dan DDM dan hasil penelitiannya menunjukkan bahwa nilai intrinsik saham menggunakan kedua pendekatan memiliki perbedaan denagn harga pasar saham tersebut. Penelitian serupa yang dilakukan oleh Rizki Ananda Khairi (2011) juga menunjukkan bahwa nilai intrinsik berdasarkan PBV memiliki perbedaan dengan harga pasarnya. Namun, pada penelitian Triyanti Fabrina Simamora (2009), nilai intrinsik berdasarkan pendekatan PBV tidak memiliki perbedaan dengan harga pasarnya.

Sejalan dengan latar belakang yang telau diuraikan, maka ditetapkan hipotesis sebagai berikut: 
$\mathrm{H}_{1}$ : Terdapat perbedaan yang sign- pertambangan batubara yang secara ifikan antara harga intrinsik saham berturut-turut terdaftar di Indeks LQ45 dengan menggunakan pendekatan selama periode penelitian yakni mulai dari Dividend Discount Model (DDM) tahun 2010 sampai dengan tahun 2014.

Pertumbuhan Berganda

$\mathrm{H}_{2}$ : Terdapat perbedaan yang signifikan antara harga pasar saham dengan harga intrinsik saham dengan menggunakan Price Earning Ratio (PER).

$\mathrm{H}_{3}$ : Terdapat perbedaan yang signifikan antara harga pasar saham dengan harga intrinsik saham dengan menggunakan Price to Book Value (PBV).

\section{Definisi Operasional Variabel}

1. Dividend Discount Model (DDM) Pertumbuhan Berganda

Penilaian harga wajar saham dengan pendekatan Dividend Discount Model (DDM) Pertumbuhan Berganda dapat dilakukan dengan rumus sebagai berikut (Tandelilin, 2001:189) :

$$
P_{0}=\sum_{t=1}^{n} \frac{D_{0}}{(1+k)^{t}}+\frac{D_{n}}{k-g_{n}} \cdot \frac{1}{(1+k)^{n}}
$$

\section{Price Earning Ratio (PER)}

Menurut Tandelilin (2001: 192),

\section{METODE ANALISIS}

\section{Populasi dan Teknik Pengambilan Sampel}

Populasi dalam penelitian ini adalah perusahaan pertambangan batubara yang terdaftar di Indeks LQ45 selama tahun 2010 - 2014. Pengambilan sampel penelitian menggunakan purposive sampling yang merupakan metode penetaoan sampel berdasarkan kriteria-kriteria tertentu. Adapun kriteria yang digunakan dalam penelitian ini adalah perusahaan rumus untuk menghitung PER dapat diturunkan dari rumus yang digunakan dalam perhitungan DDM. Satuan yang digunakan dalam PER adalah rasio atau kali, sedangkan untuk satuan nilai intrinsik berdasarkan pendekatan PER adalah harga atau rupiah. Adapun rumus untuk menilai saham berdasarkan berdasarkan pendekatan pendekatan ini adalah sebagai berikut :

$$
P E R=\frac{\text { Harga per Lembar Saham }}{E P S}
$$


Dan untuk menghitung nilai Teknik Analisis Data

intrinsik saham menggunakan rumus (Jogiyanto, 2008:143) :

$$
P_{0}=\text { Estimasi PER } \times E_{1}
$$

\section{Price to Book Value (PBV)}

Penilaian saham menggunakan pendekatan Price to Book Value (PBV) dapat dihitung dengan rumus sebagai berikut (Jogiyanto , 2007:129) :

$$
\text { Rasio PBV }=\frac{\text { Harga Pasar Saham }}{\text { Nilai Buku per Lembar Saham }}
$$

Nilai buku per lembar saham adalah,

$$
\frac{\text { Total Ekuitas }}{\text { Jumlah Saham Beredar }}
$$

Penelitian ini menggunakan analisis fundamental dan uji statistik dalam teknik analisis datanya. Analsis fundamental untuk menghitung harga wajar saham (nilai intrinsik) dilakukan dengan menggunakan pendekatan Dividend Dis-count Model Pertumbuhan Berganda, Price Earning Ratio, dan Price to Book Value. Sedangkan untuk uji statistik yang digunakan dalam penelitian ini ialah uji normalitas kolmogrov-smirnov dan uji signifikansi perbedaan paired sample $t$ test.

\section{HASIL ANALISIS}

\section{Analisis Fundamental}

\begin{tabular}{|c|c|c|c|c|}
\hline \multirow{2}{*}{ Tahun } & \multirow{2}{*}{$\begin{array}{l}\text { Harga } \\
\text { Pasar } \\
\text { Saham }\end{array}$} & \multicolumn{3}{|c|}{ Nilai Intrinsik } \\
\hline & & DDM & PER & PBV \\
\hline 2010 & 2.550 & 3.332 .35 & $2.719,98$ & 580,769 \\
\hline 2011 & 1.770 & 9.10 & $1.977,81$ & 692,369 \\
\hline 2012 & 1.590 & 181.77 & $1.732,12$ & 905,465 \\
\hline 2013 & 1.090 & 162.90 & $1.142,88$ & $1.217,531$ \\
\hline 2014 & 1.040 & $\begin{array}{c}- \\
6.220,78 \\
\end{array}$ & $1.072,99$ & $1.267,161$ \\
\hline $\begin{array}{c}\text { Rata- } \\
\text { rata }\end{array}$ & 1.608 & -1.840 & 1.729 & 933 \\
\hline
\end{tabular}

Tabel 1. Perbandingan Harga Pasar Saham dengan Harga Wajar Saham PT. Adaro Energy Tbk Tahun 2010-2014

Sumber: Data diolah 
Analisis fundamental ini dilakukan untuk mengetahui harga wajar saham atau nilai intrinsik dari masing-masing sampel pada setiap tahun periode penelitian. Adapun hasil nilai intrinsik ketiga sampel dan perbandingannya dengan harga pasar saham adalah sebagai berikut:

Berdasarkan tabel 1 diketahui bahwa rata-rata nilai intrinsik saham PT. Adaro Energy Tbk selama tahun 2010-2014 dengan menggunakan pendekatan DDM dan PBV berada pada kondisi overvalued atau nilai intrinsik lebih rendah dari harga pasar saham. Sedangkan pada pendekatan PER, saham berada pada kondisi undervalued atau nilai intrinsik lebih tinggi dari harga pasar saham.

Tabel 2 menunjukkan bahwa ratarata nilai intrinsik saham PT. Indo Tambangraya Megah, Tbk., selama tahun 2010-2014 menggunakan pendekatan DDM dan PBV adalah berada pada kondisi overvalued atau saham dinilai mahal oleh investor dan berdasarkan pendekatan PER berada pada kondisi undervalued atau dinilai murah oleh investor.

Tabel 2. Perbandingan Harga Pasar Saham dengan Harga Wajar Saham PT. Indo Tambangraya Megah, Tbk., Tahun 2010-2014

\begin{tabular}{|c|c|c|c|c|}
\hline \multirow{2}{*}{ Tahun } & \multirow{2}{*}{$\begin{array}{c}\text { Harga } \\
\text { Pahar }\end{array}$} & \multicolumn{3}{|c|}{ Nilai Intrinsik } \\
\cline { 3 - 5 } & DDM & PER & PBV \\
\hline 2010 & 50.750 & $5.627,54$ & $54.446,5$ & $5.737,31$ \\
\hline 2011 & 38.650 & $56.451,27$ & $52.939,15$ & $8.673,79$ \\
\hline 2012 & 41.550 & 499,96 & $43.327,81$ & $8.578,78$ \\
\hline 2013 & 28.500 & $6.782,26$ & $29.367,31$ & $10.397,53$ \\
\hline 2014 & 15.375 & $16.892,63$ & $15.894,52$ & $9.893,47$ \\
\hline $\begin{array}{c}\text { Rata- } \\
\text { Rata }\end{array}$ & $\mathbf{3 4 . 9 6 5}$ & $\mathbf{1 7 . 2 5 0 , 7 3}$ & $\mathbf{3 9 . 1 9 5 , 0 5}$ & $\mathbf{8 . 6 5 6}$ \\
\hline
\end{tabular}

Sumber: Data diolah 


\section{Performance - Vol.23 No.2 September 2016}

Tabel 3. Perbandingan Harga Pasar Saham dengan Harga

Wajar Saham PT. Bukit Asam, Tbk., Tahun 2010-2014

\begin{tabular}{|c|c|c|c|c|}
\hline \multirow[b]{2}{*}{ Tahun } & \multirow{2}{*}{$\begin{array}{l}\text { Harga } \\
\text { Pasar } \\
\text { Saham }\end{array}$} & \multicolumn{3}{|c|}{ Nilai Intrinsik } \\
\hline & & DDM & PER & PBV \\
\hline 2010 & 22.950 & $10.905,71$ & $25.851,55$ & $2.763,18$ \\
\hline 2011 & 17.350 & -418.02 & $19.972,06$ & $3.543,64$ \\
\hline 2012 & 15.000 & $19.592,84$ & $17.193,76$ & $3.691,27$ \\
\hline 2013 & 10.200 & $2.153,34$ & $11.293,73$ & $3.277,40$ \\
\hline 2014 & 12.500 & $1.769,19$ & $14.392,75$ & $3.763,17$ \\
\hline $\begin{array}{l}\text { Rata- } \\
\text { Rata }\end{array}$ & 15.600 & $6.800,61$ & $17.740,76$ & 3.408 \\
\hline
\end{tabular}

Sumber: Data diolah

Berdasarkan tabel 3 di atas, ratarata nilai intrinsik saham PT. Bukit Asam, Tbk., selama tahun 2010-2014 dengan menggunakan pendekatan DDM dan PBV berada pada kondisi overvalued atau nilai intrinsik lebih rendah dari harga pasar saham serta dinilai mahal oleh investor. Sedangkan pada pendekatan PER, saham berada pada kondisi undervalued atau nilai intrinsik lebih tinggi dari harga pasar saham dan dinilai murah oleh investor.

\section{Uji Statistik}

\section{a. Uji Normalitas}

Uji normalitas dilakukan untuk mengetahui apakah data atau nilai residual yang telah distandarisasi pada model regresi berdistribusi normal atau tidak (Suliyanto, 2011:69). Pada penelitian ini uji normalitas dilakukan dengan menggunakan uji statistik non-parametik Kolomogorov-Smirnov menggunakan software SPSS 17.0 version for windows. Adapun hasil uji normalitas Kolomogorov-Smirnov adalah sebagai berikut:

Sumber: Output software SPSS versi 17.0 for windows

Kriteria pengujian pada analisis uji normalitas Kolmogorov-Smirnov yakni jika $\mathrm{K}$ hitung < $\mathrm{K}$ table, atau jika Signifikansi (Sig.) $>\alpha$, maka nilai residual atau data terstandarisasi berdistribusi normal. Berdasarkan tabel di atas, diketahui bahwa nilai Asymp. Sig. (2-tailed) adalah sebesar 0,200 dan lebih besar 
Tabel 4. Hasil Analisis Uji Normalitas One-Sample

Kolmogorov-Smirnov Test.

\begin{tabular}{llr}
\multicolumn{3}{c}{ Kolmogorov-Smirnov Test. $^{2}$} \\
\hline & \multicolumn{2}{c}{$\begin{array}{c}\text { Standardized } \\
\text { Residual }\end{array}$} \\
\hline $\mathrm{N}$ & & 15 \\
\hline Normal Parameters $^{\mathrm{a}, \mathrm{b}}$ & Mean &, 0000000 \\
& Std. &, 88640526 \\
& Deviation &, 143 \\
\hline Most Extreme & Absolute &, 143 \\
Differences & Positive &,- 117 \\
\hline Test Statistic & Negative &, 143 \\
\hline Asymp. Sig. (2-tailed) & &, $200^{\mathrm{c}, \mathrm{d}}$ \\
\hline
\end{tabular}

dari tingkat signifikansi $(\alpha)$ sebesar 0,05. Hal ini berarti data pada penelitian ini terdistribusi normal sehingga uji signifikansi perbedaan yang dapat dilakukan adalah dengan menggunakan paired sample t-test.

\section{b. Uji Signifikansi Perbedaan}

Setelah dilakukan uji normalitas pada data penelitian dan hasilnya menunjukkan data terdistribusi normal, maka langkah selanjutnya yang dapat diambil yakni melakukan pengujian signifikansi perbedaan dengan menggunakan uji paired sample t-test. Adapun hasil uji signifikansi perbedaan paired sample t-test adalah sebagai berikut:

Tabel 5. Hasil Uji Paired Sampel T-Test Berdasarkan Pendekatan Dividend Discount Model (DDM) Pertumbuhan Berganda

\begin{tabular}{|c|c|c|c|c|c|c|c|c|c|}
\hline & \multicolumn{9}{|c|}{ Paired Difference } \\
\hline & & \multirow[t]{2}{*}{ Mean } & \multirow[t]{2}{*}{$\begin{array}{c}\text { Std. } \\
\text { Deviation }\end{array}$} & \multirow{2}{*}{$\begin{array}{l}\text { Std. } \\
\text { Error } \\
\text { Mean }\end{array}$} & \multicolumn{2}{|c|}{$\begin{array}{l}\text { 95\% Confidence } \\
\text { Interval of the } \\
\text { Difference }\end{array}$} & \multirow[t]{2}{*}{$\mathbf{t}$} & \multirow[t]{2}{*}{ df } & \multirow{2}{*}{$\begin{array}{c}\text { Sig } \\
(2- \\
\text { tailed })\end{array}$} \\
\hline & & & & & Lower & Upper & & & \\
\hline $\begin{array}{c}\text { Pair } \\
1\end{array}$ & $\begin{array}{l}\text { Harga } \\
\text { Pasar - } \\
\text { DDM }\end{array}$ & 9987,18 & 16411,80 & 4237.51 & 898,62 & 19075,73 & 2,357 & 14 & 0,034 \\
\hline
\end{tabular}

Sumber: Output software SPSS versi 17.0 for windows 


\section{Performance - Vol.23 No.2 September 2016}

Tabel 6. Analisis Hasil Uji Paired Sampel T-Test Berdasarkan Pendekatan Dividend Discount Model (DDM) Pertumbuhan Berganda

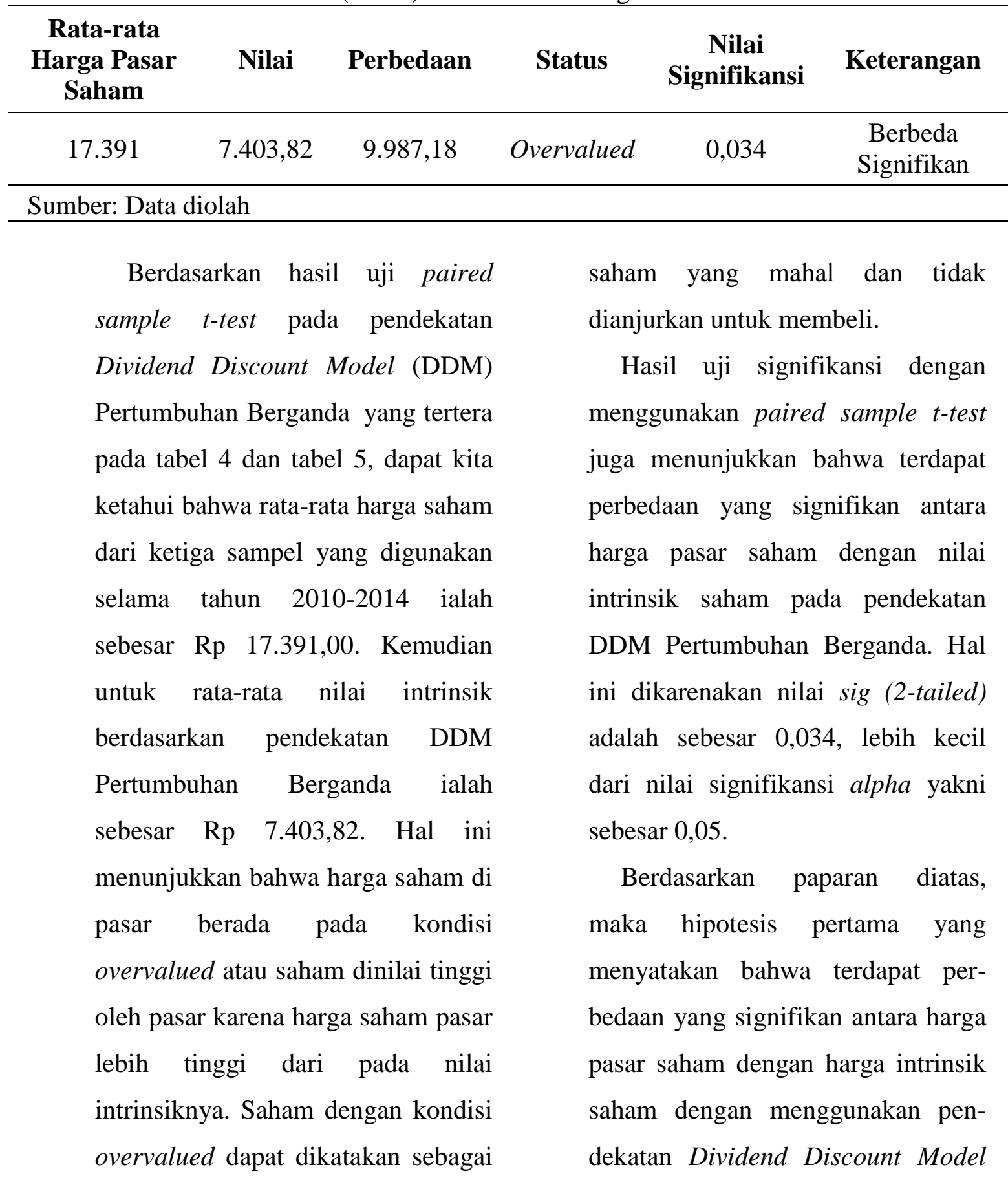


(DDM) Pertumbuhan Berganda diterima.

Tabel 7. Hasil Uji Paired Sampel T-Test Berdasarkan Pendekatan Price Earning Ratio (PER)

\begin{tabular}{|c|c|c|c|c|c|c|c|c|c|}
\hline & & \multicolumn{8}{|c|}{ Paired Difference } \\
\hline & & \multirow[b]{3}{*}{ Mean } & \multirow{3}{*}{$\begin{array}{c}\text { Std. } \\
\text { Deviation }\end{array}$} & \multirow{3}{*}{$\begin{array}{l}\text { Std. } \\
\text { Error } \\
\text { Mean }\end{array}$} & \multirow{2}{*}{\multicolumn{2}{|c|}{$\begin{array}{l}\text { 95\% Confidence } \\
\text { Interval of the } \\
\text { Difference }\end{array}$}} & \multirow[b]{3}{*}{$\mathbf{t}$} & \multirow[b]{3}{*}{ df } & \multirow{3}{*}{$\begin{array}{l}\text { Sig (2- } \\
\text { tailed) }\end{array}$} \\
\hline & & & & & & & & & \\
\hline & & & & & Lower & Upper & & & \\
\hline $\begin{array}{l}\text { Pair } \\
1\end{array}$ & $\begin{array}{l}\text { Harga } \\
\text { Pasar - } \\
\text { PER }\end{array}$ & $-2163,99$ & 3553,32 & 917,46 & $-4131,75$ & $-196,23$ & $-2,359$ & 14 & 0,033 \\
\hline
\end{tabular}

Sumber: Output software SPSS versi 17.0 for windows

Tabel 8. Analisis Hasil Uji Uji Paired Sampel T-Test Berdasarkan Pendekatan Price Earning Ratio (PER)

\begin{tabular}{cccccc}
\hline $\begin{array}{c}\text { Rata-rata } \\
\text { Harga Pasar } \\
\text { Saham }\end{array}$ & Nilai & Perbedaan & Status & $\begin{array}{c}\text { Nilai } \\
\text { Signifikansi }\end{array}$ & Keterangan \\
\hline 17.391 & $19.554,99$ & $-2.163,99$ & Undervalued & 0,033 & $\begin{array}{c}\text { Berbeda } \\
\text { Signifikan }\end{array}$ \\
\hline Sumber: Data diolah & & & & \\
\hline
\end{tabular}

Hasil uji paired sample t-test pada pendekatan Price Earning Ratio (PER) menunjukkan terdapat perbedaan yang signifikan antara harga harga pasar saham dengan nilai intrinsik saham. Hal ini ditunjukkan dengan nilai sig (2tailed) pada tabel 22 yakni sebesar 0,033, dimana nilai tersebut lebih kecil dari nilai signifikansi alpha sebesar 0,05 .
Selain itu, berdasarkan tabel 8 kita juga dapat mengetahui bahwa harga saham PT. Adaro Energy Tbk, PT. Indo Tambangraya Megah Tbk dan PT. Bukit Asam Tbk selama tahun 2010-2014 berada pada kondisi undervalued. Hal ini karena rata-rata nilai intrinsik atau harga wajar saham ketiga sampel yakni sebesar Rp 19.554,99 ialah lebih besar dari rata-rata harga saham di pasar yakni sebesar Rp 17.391,00. 
Saham pada kondisi undervalued menunjukkan saham dinilai rendah oleh pasar dan dapat dikatakan sebagai saham yang murah.

Berdasarkan penjelasan diatas, maka hipotesis kedua yang men- yatakan bahwa terdapat perbedaan yang signifikan antara harga pasar saham dengan harga intrinsik saham dengan menggunakan pendekatan Price Earning Ratio (PER) diterima.

Tabel 9. Hasil Uji Paired Sampel T-Test Berdasarkan Pendekatan Price to Book Value (PBV)

\begin{tabular}{|c|c|c|c|c|c|c|c|c|c|}
\hline & & \multicolumn{8}{|c|}{ Paired Difference } \\
\hline & & \multirow[b]{3}{*}{ Mean } & \multirow{3}{*}{$\begin{array}{c}\text { Std. } \\
\text { Deviation }\end{array}$} & \multirow{3}{*}{$\begin{array}{l}\text { Std. } \\
\text { Error } \\
\text { Mean }\end{array}$} & \multirow{2}{*}{\multicolumn{2}{|c|}{$\begin{array}{l}\text { 95\% Confidence } \\
\text { Interval of the } \\
\text { Difference }\end{array}$}} & \multirow[b]{3}{*}{$\mathbf{t}$} & \multirow[b]{3}{*}{ df } & \multirow{3}{*}{$\begin{array}{l}\text { Sig (2- } \\
\text { tailed) }\end{array}$} \\
\hline & & & & & & & & & \\
\hline & & & & & Lower & Upper & & & \\
\hline $\begin{array}{l}\text { Pair } \\
1\end{array}$ & $\begin{array}{l}\text { Harga } \\
\text { Pasar - } \\
\text { PBV }\end{array}$ & 13058,81 & 13803,25 & 3563,98 & 5414,83 & 20702,80 & 3,664 & 14 & 0,003 \\
\hline
\end{tabular}

Sumber: Output software SPSS versi 17.0 for windows

Tabel 10. Analisis Hasil Uji Uji Paired Sampel T-Test Berdasarkan Pendekatan Price to Book Value (PBV)

\begin{tabular}{cccccc}
\hline $\begin{array}{c}\text { Rata-rata } \\
\text { Harga Pasar } \\
\text { Saham }\end{array}$ & Nilai & Perbedaan & Status & $\begin{array}{c}\text { Nilai } \\
\text { Signifikansi }\end{array}$ & Keterangan \\
\hline 17.391 & $4.334,19$ & $13.056,81$ & Overvalued & 0,003 & $\begin{array}{c}\text { Berbeda } \\
\text { Signifikan }\end{array}$ \\
\hline
\end{tabular}

Sumber: Data diolah

Penilaian harga wajar saham menggunakan pendekatan Price to Book Value (PBV) ialah penilaian yang dilakukan dengan cara membandingkan harga pasar saham dengan nilai buku saham. Pada kedua tabel diatas, hasil uji statistik paired sample t-test menunjukkan harga pasar saham memiliki beda yang signifikan dengan nilai intrinsik berdasarkan pendekatan PBV. Perbedaan ini ditunjukkan oleh nilai sig (2-tailed) yang lebih kecil dari nilai signifikansi alpha. Sig (2-tailed) menunjukkan nilai 


\section{Performance - Vol.23 No.2 September 2016}

0,003 lebih kecil dari nilai signifikansi alpha yakni 0,05.

Nilai intrinsik saham rata-rata ketiga sampel berdasarkan hasil uji paired sample t-test memiliki nilai sebesar $\mathrm{Rp}$ 4.334,19 dan rata-rata harga pasar saham adalah sebesar Rp 17.319,00. Hal ini berarti nilai intrinsik saham lebih kecil dari harga pasar saham atau dapat dikatakan saham berada pada kondisi overvalued (saham mahal). Berdasarkan penjelasan diatas, maka hipotesis ketiga yang menyatakan bahwa terdapat perbedaan yang signifikan antara harga pasar saham dengan harga intrinsik saham dengan menggunakan pendekatan Price to Book Value (PBV) diterima.

\section{KESIMPULAN}

1. Uji signifikansi paired sample t-test antara harga pasar saham dengan nilai intrinsik saham berdasarkan pendekatan Dividend Discount Model (DDM) Pertumbuhan Berganda menunjukkan terdapat perbedaan yang signifikan antara harga pasar saham dengan nilai intrinsik saham. Selain itu,

berdasarkan hasil uji signifikansi ini pun, rata-rata harga pasar saham dan rata-rata nilai intrinsik menunjukkan saham berada pada kondisi overvalued.

2. Uji signifikansi paired sample t-test antara harga pasar saham dengan nilai intrinsik saham berdasarkan pendekatan Price Earning Ratio (PER) menunjukkan terdapat perbedaan yang signifikan antara harga pasar saham dengan nilai intrinsik saham. Selain itu, berdasarkan hasil uji signifikansi ini pun, rata-rata harga pasar saham dan rata-rata nilai intrinsik menunjukkan saham berada pada kondisi undervalued.

3. Uji signifikansi paired sample t-test antara harga pasar saham dengan nilai intrinsik saham berdasarkan pendekatan Price to Book Ratio (PBV) menunjukkan terdapat perbedaan yang signifikan antara harga pasar saham dengan nilai intrinsik saham. Selain itu, berdasarkan hasil uji signifikansi ini pun, rata-rata harga pasar saham dan rata-rata nilai intrinsik menunjukkan saham berada pada kondisi overvalued.

\section{IMPLIKASI}


1. Saham dengan kondisi overvalued pada penelitian ini adalah saham yang dinilai tinggi oleh pasar atau saham dengan harga yang cukup mahal. Bagi investor dengan orientasi jangka pendek sebaiknya melakukan penjualan saham (selling) karena harga yang semakin tinggi akan merugikan investor. Untuk investor berorientasi jangka panjang, ada baiknya untuk mempertahankan saham (hold). Hal ini karena pada grafik perkembangan harga saham menunjukkan nilai intrinsik ketiga sampel berdasarkan pendekatan DDM dan PBV mengalami kenaikan, dimana ini berarti kepercayaan pasar terhadap prospek perusahaan semakin meningkat. Hal ini juga didukung dengan pergerakan harga saham sektor industri pertambangan batubara pada awal tahun hingga pertengahan tahun 2016 mengalami kenaikan.

2. Saham dengan kondisi undervalued atau saham dengan harga yang cukup rendah, pada kondisi ini para investor disarankan untuk membeli saham karena ini akan menguntungkan para investor, terlebih pada investor dengan orientasi jangka panjang. Hal ini karena adanya kecenderungan harga saham

yang bergerak naik selama tahun 2016 serta kecenderungan perkembangan fundamental ketiga sampel perusahaan menunjukkan adanya peningkatan.

3. Berdasarkan hasil perhitungan harga pasar saham dan nilai intrinsik saham menggunakan pendekatan Dividend Discount Model (DDM) Pertumbuhan Berganda, Price Earning Ratio (PER) dan Price to Book Ratio (PBV) selama tahun 2010-2014, saham PT. Bukit Asam Tbk merupakan perusahaan dengan tingkat penurunan terkecil selama periode penelitian sehingga saham PT. Bukit Asam Tbk ini lah yang disarankan untuk dibeli oleh para investor.

4. Berdasarkan hasil perhitungan harga pasar saham dan nilai intrinsik saham, pendekatan Price Earning Ratio (PER) merupakan metode yang paling relevan digunakan dalam penilaian saham karena nilai intrinsik berdasarkan pendekatan PER cenderung bergerak searah dengan harga pasar saham.

\section{DAFTAR PUSTAKA}


Brigham, Eugane F. dan Joel. F. Houston. 2006. Manajemen Keuangan Buku I. Erlangga. Jakarta.

Cahyadi, Hadi. 2014. Penilaian Harga Wajar Saham pada Bank ABC Menggunakan Pendekatan Pasar (Metode Perusahaan Pembanding dan Metode Transaksi Sebelumnya). Jurnal Akuntansi Universitas Tarumanegara. Vol. XVIII. N0. 1 hal. 130-140. Januari 2014.

Darmadji, Tjiptono dan Hendry $\mathrm{M}$. Fakhruddin. 2011. Pasar Modal di Indonesia Pendekatan Tanya Jawab. Edisi Ketiga. Salemba Empat. Jakarta.

Hartono, Jogiyanto. 2013. Teori Portofolio dan Analisis Investasi. Edisi Ketujuh. Badan Penerbit Fakultas Ekonomi Universitas Gajah Mada. Yogyakarta.

Fayana, Ernia dan Singgih Jatmika. 2012. Penilaian Harga Wajar Saham dengan Menggunakan Metode Dividend Discount Model (DDM) dan Price to Book Value (PBV Ratio) pada Sektor Perbankan yang Termasuk Saham LQ45 di $B E I$. Skripsi. Universitas Gunadarma. Jakarta.

Khairi, Elvianna. 2011. Penilaian Harga Wajar Saham dengan Price Earning Ratio PT. Bank Mandiri Tbk, PT. Bank Rakyat Indonesia
Tbk dan PT. Bank Negara Indonesia Tbk. Skripsi. Universitas Sumatera Utara. Medan.

Khairi, Rizky Ananda. 2014. Penilaian Harga Wajar Saham dengan Relative Valuation Techniques PT. Bank Mandiri Tbk dan PT. Bank Rakyat Indonesia Tbk. Skripsi. Universitas Sumatera Utara. Medan.

Khairi, Sherly Emita. 2010. Valuasi Harga Wajar Saham Sektor Perbankan yang Go Public di BEI. Skripsi. Universitas Sumatera Utara. Medan.

Husnan, Suad. 2005. Dasar-dasar Teori Portofolio dan Analisis Sekuritas. Edisi Keempat. Unit Penerbit dan Percetakan AMP YKPN. Yogyakarta.

Hutapea, Ecryna Cyntia., dkk. 2012. Analisis Valuasi Nilai Wajar Saham PT. Adaro Energy Tbk Menggunakan Metode Free-Cash Flow to Firm (FCFF). Journal of Applied Finance and Accounting 5(2), 240-270.

Manurung, Andrian Lorand. 2007. Valuasi Harga Wajar Saham PT. Telekomunikasi Indonesia Tbk. Skripsi. Universitas Sumatera Utara. Medan.

Pratama, Rendy., dkk. 2014. Analisis Fundamental Untuk Menilai Kewajaran Harga Saham dengan 
Dividend Discount Model (DDM) dan Price Earning Ratio (PER) Sebagai Dasar Pengambilan Keputusan Investasi (Studi pada Perusahaan Sektor Property dan Real Estate yang Listed di Bursa Efek Indonesia Tahun 2010-2013). Jurnal Administrasi Universitas Brawijaya Malang. Vol. 17. No. 1. Desember 2014.

Pratiwi, Vita Erika. 2015. Penilaian Harga Wajar Saham Menggunakan Pendektan Dividend Discount Model, Price to Book Value dan Price Earning Ratio (Studi pada Perusahaan Rokok yang Terdaftar di Bursa Efek Indonesia Periode 2009-2013). Skripsi. Universitas Jenderal Soedirman. Purwokerto.

Putra, I Putu Darma. 2009. Analisis Valuasi Saham pada PT. Indofood Sukses Makmur Tbk, PT. Gudang Garam Tbk, dan PT. Unilever Tbk. Skripsi. Universitas Gunadarma. Depok.

Saputra, Bayu Dwi., dkk. 2015. Analisis Penetapan Harga Intrinsik Saham dengan Menggunakan Metode Price Earning Ratio (PER) Sebagai Dasar Keputusan Investasi Saham (Studi pada Perusahaan Sektor Konstruksi Bangunan yang Terdaftar di Bursa Efek Indonesia Periode 20102013). Jurnal Administrasi Bisnis
Universitas Brawijaya Malang. Vol. 23. No. 1. Juni 2015.

Simamora, Triyanti Fabrina. 2009. Penilaian Kewajaran Harga Saham dengan Pendekatan Analisis Fundamental pada Sektor Telekomunikasi di Bursa Efek Indonesia (BEI). Skripsi. Universitas Sumatera Utara. Medan.

Sugiyono. 2013. Statistika untuk Penelitian. Alfabeta. Bandung.

Sugiyono. 2015. Metode Penelitian Pendidikan (Pendekatan Kuantitatif, Kualitatif dan $R \& D)$. Alfabeta. Bandung.

Suliyanto. 2011. Ekonometrika Terapan: Teori dan Aplikasi dengan SPSS. CV. Andi Offset. Yogyakarta.

Tandelilin, Eduardus. 2001. Analisis Investasi dan Manajemen Portofolio. Edisi Pertama. Badan Penerbit Fakultas Ekonomi Universitas Gajah Mada. Yogyakarta.

Wijaya, Avvita Putri., dkk. 2015. Analisis Fundamental dengan Pendekatan Dividen Discount Model (DDM) Untuk Menilai Kewajaran Harga Saham (Studi pada Perusahaan Sub Sektor Semen yang Terdaftar di Bursa Efek Indonesia Periode 2011-2013). Jurnal Administrasi Universitas Brawijaya Malang. Vol.26. No. 2. September 2015. 
Performance - Vol.23 No.2 September 2016

Yulfita, Ulfa. 2013. Penilaian Harga

Wajar Saham Sektor Manufaktur

yang Terfatar di Bursa Efek

Indonesia (Periode 2009-2011).

Jurnal EMBA ISSN 2302-1174.

Vol. 1. No. 3. Hal 1089-1099.

September 2013.

www.bi.go.id (diakses pada 2016)

www.bp.com (diakses pada 2016)

www.finance.yahoo.co.id (diakses pada 2016)

www.idx.co.id (diakses pada 2016)

www.sahamok.com (diakses pada 2016)

www.indonesia-investment.com (diakses

pada 2016) 